\title{
Outcomes of Intrathecal Baclofen (ITB) Therapy in Spacticity
}

\author{
Spastisitede Intratekal Baklofen Tedavisi Sonuçları
}

\author{
Tanju UCAR ${ }^{1}$, Saim KAZAN ${ }^{1}$, Umut TURGUT ${ }^{1}$, Nehir KARAMAN SAMANCI ${ }^{2}$ \\ ${ }_{1}$ Akdeniz University, Faculty of Medicine, Department of Neurosurgery, Antalya, Turkey \\ ${ }^{2}$ Akdeniz University, Faculty of Medicine, Department of Physical Medicine and Rebabilitation, Antalya, Turkey
}

Correspondence address: Tanju UCAR / E-mail: tucar@akdeniz.edu.tr

\begin{abstract}
AIM: Spasticity is associated with various neurological conditions. Intrathecal baclofen (ITB) is one of the popular treatments for severe spasticity. In this paper we present our experience in treating 30 patients with both spinal and supraspinal spasticity with chronic infusion of Baclofen to evaluate the long term efficacy of this treatment on spasticity, disability and pain, and to evaluate the side effects of intrathecal Baclofen.

MATERIAL and METHODS: The medical records of 30 patients who underwent baclofen pump placement from 2000 to 2010 under Department of Neurosurgery at the University of Akdeniz at Antalya/Turkey, were reviewed. All study subjects had diffuse chronic, severe, and generalized spasticity (Ashworth score $\geq 3$ ), and had shown inadequate response to various oral antispastic drugs including baclofen. All patients were evaluated by means of the Ashworth score, spasm frequency, Barthel index, Rankin scales and VAS.
\end{abstract}

RESULTS: Spasticity and spasm frequency and pain scores were clinically and statistically decreased in all patients.

CONCLUSION: ITB therapy increases the quality of lifestyle and functional independence by reducing not only cerebral but also spinal related spasticity in appropriately selected cases.

KEYWORDS: Baclofen, Intrathecal, Spasticity, Neurological disorders, Intrathecal Baclofen Therapy

öz

AMAÇ:Spastisite değişiknörolojik rahatsızlıklarla birlikte görülebilir. Intratekal baklofen(ITB) spastisite tedavisindeki yeni tedavi seçeneklerinden birisidir. Çalışmamızda spinal ve serebral nedenlere bağlı spastisite tedavisinde ITB tedavisinin uzun dönem sonuçları, ağrı ve yaşam kalitesi üzerine etkilerini araştırdık.

YÖNTEM ve GEREÇ: 2000-2010 yılları arasında kliniğimizde ITB uygulanan 30 hastanın sonuçları analiz edildi. Tüm olgular yaygın, kronik ve oral antispastiklere ve rehabilitasyona cevap vermeyen ağır olgulardı. Bu olgular Aashworth skoru, spasm sıklık skoru, Barthel indeksi ve Rankin skalası kullanılarak değerlendirildi.

BULGULAR: Sonuçta değerlendirilen tüm parametrelerde belirgin düzelmeler görüldü.

SONUÇ: Iyi seçilmiş olgularda ITB tedavisi yalnızca serebral değil spinal kökenli spastisite üzerinde de yaşam kalitesini ve fonksiyonel düzelmeyi sağlayan bir tedavi seçeneğidir.

ANAHTAR SÖZCÜKLER: Baklofen, İntratekal, Spastisite, Nörolojik bozukluklar, İntratekal Baklofen Tedavisi

\section{INTRODUCTION}

Spasticity is associated with a various neurological conditions such as cerebral palsy (CP), brain injury (BI), spinal cord injury $(\mathrm{SCl})$, and other neurological disorders. Two decades ago, therapeutic approaches were restricted to nerve blocks, electrical stimulation, and destructive neurosurgical procedures or oral medication with antispastic agents such as baclofen, tizanidine or diazepam $(5,13)$. Baclofen, a synthetic structural analog of g-aminobutyric acid, acts on the central nervous system by stimulation of the $g$-aminobutyric acidType $B$ receptor subtype in the central nervous system. The precise mechanism of action of baclofen as a muscle relaxant and antispasticity agent is not fully understood. Baclofen inhibits both monosynaptic and polysynaptic reflexes at the spinal level, possibly by decreasing excitatory neurotransmitter release from primary afferent terminals, although actions at supraspinal sites may also occur and contribute to its clinical effect(4)

For patients with spasticity who prove to be refractory or not well controlled with oral baclofen, intrathecal baclofen (ITB) via pump is an effective therapeutic option. Intrathecal baclofen (ITB) was first proposed in the treatment of spasticity by Penn and Kroin in 1984 (21). Intrathecally delivered liquid baclofen acts directly and selectively at spinal level. Intrathecally, baclofen acts on the spinal cord directly by agonizing GABA receptors. Levels of $400 \mu \mathrm{g} / \mathrm{mL}$ can be measured in 
the cerebrospinal fluid (CSF) during pump administration which is greater than the level typically obtained with oral administration (12 to $96 \mu \mathrm{g} / \mathrm{mL}$ ). As a result much smaller doses are required, the central side effects of oral baclofen such as drowsiness or confusion are minimal, and therapeutic responses are greatly enhanced.

The clinical efficacy of intrathecal baclofen in reducing spasticity has been demonstrated by several studies $(1,4,5,7,8,14,17,18,24)$. However, the number of more detailed studies evaluating the functional situations of the patients by pain, level of mobilization and care problems after ITB therapy is rather inadequate in literature. Possible outcomes vary greatly, based on the underlying neurologic level of function, but may include improved ambulation or wheelchair seating, reduced spasticity-related pain, improved sleep, and easier positioning and care giving (19). The aim of continuous intrathecal baclofen (ITB) infusion is not to abolish but rather to decrease spasticity.

Treatment is focused on first of all improving range of motion, facilitating movement, reducing the risk of contracture development, and secondly, and most importantly, on improving the quality of life.

In this paper we present our experiences in treating 30 patients with both spinal and supraspinal spasticity with chronic infusion of Baclofen to evaluate the long- term efficacy of this treatment on the spasticity, disability and pain, and to evaluate the side effects of intrathecal Baclofen.

\section{MATERIAL and METHODS}

\section{Patients}

The medical records of 30 patients ( 19 male, 11 female) who underwent baclofen pump placement from 2000 to 2010 under the Department of Neurosurgery and followed up at the Department of Physical Medicine and Rehabilitation at Akdeniz University, Antalya / Turkey were reviewed. All study subjects had diffuse chronic, severe, and generalize spasticity of at least 3 months duration (Ashworth score $\geq 3$ ), and had failed to respond adequately or had experienced untoward side effects from various oral antispastic drugs included baclofen. The patients were divided into two categories according to the etiology of spasticity: 18 had supraspinal spasticity $(\mathrm{CP}, \mathrm{BI})$ and 12 had $\mathrm{SCl}$ at different levels (from $\mathrm{C} 8$ to T11). The main characteristics of the patients are seen on Table I.

\section{Screening procedures}

After signing an informal consent form for ITP therapy, patients underwent a screening procedure to determine responsiveness to ITP. All subjects were given a test bolus $50 \mu \mathrm{g}$ baclofen by lumbar puncture. Ashworth scores were measured 4 and 6 hours before and after the injection. The dose of baclofen was increased by $50 \mu \mathrm{g}$ if the mean Ashworth scores decreased by less than 2 points after the initial dose. The response was considered positive if there was an improvement of two or more points on the Ashworth scores.
The initial ITB dose with an implanted pump is usually 100 microg/d, which is twice the usual test bolus dose.

\section{Pump implantation}

In case of positive response, a continuous infusion pump was implanted by the first author (TU). ITP was implanted under general anesthesia. The catheter was placed into the lumbar subarachnoid space through a percutaneous technique. The level of the catheter tip was T10-11 in all patients but the C7-T1 level was preferred in patients suffering from tetraparesis according to the literature (16). The pump was placed in the subcutaneous pocket in the lower quadrant of the abdomen and connected to the catheter. The standard surgical procedure involves implanting the pump in the lateral abdominal wall in the subcutaneous plane. In pediatric cases, we have used the subfascial implantation technique described by Grabb and Pittman $(12,6) .28$ patients received the SynchroMed pump (Medtronic, Minneapolis, USA), and 2 patients a constant flow (Archimedes, Codman, Switzerland) pump system. The surgical complications and side effects of the treatment were also recorded.

Pump Refills. The pump has a reservoir that holds the medication being pumped. In the current Synchromed pumps, this volume capacity is $10-18$ or $20-40 \mathrm{ml}$. The pump is refilled by a sterile technique through a central access port. The software for the telemetry unit calculates automatically an alarm date based on $2 \mathrm{ml}$ of the residual remaining in the pump reservoir. However, our clinical observation has shown some return of spasticity symptoms in patients before this point.

\section{Outcome measures and follow-up}

All the patients were evaluated before the treatment, during the intrathecal bolus test with ITB, and follow up period (two months after the pump implantation, then every 3 months). The follow-up duration was defined as the period of time between the implantation and the assessment, or pump withdrawal, or death. Patients' evaluation was done using spasticity measures (Ashworth Scale) (2).

Activities of daily living were measured using the Barthel Index (15) preoperatively and the following year. Handicap was measured by the Rankin Skale (23).

Pain was assessed with a self-reported visual analog scale ranging from 0 to 10 ( 0 was no pain, 10 was the worst pain). If patients were not able to answer the questionnaire given them because of their cognitive deficits, information about them was obtained from their relatives if available. All measurements were administered by the same examiner (NS).

\section{Statistical analyses}

All data are reported as mean \pm SD. Pre- and post-ITP data were compared by means of Student's T test. Statistical analyses were performed using the SPSS 13.0 software. 


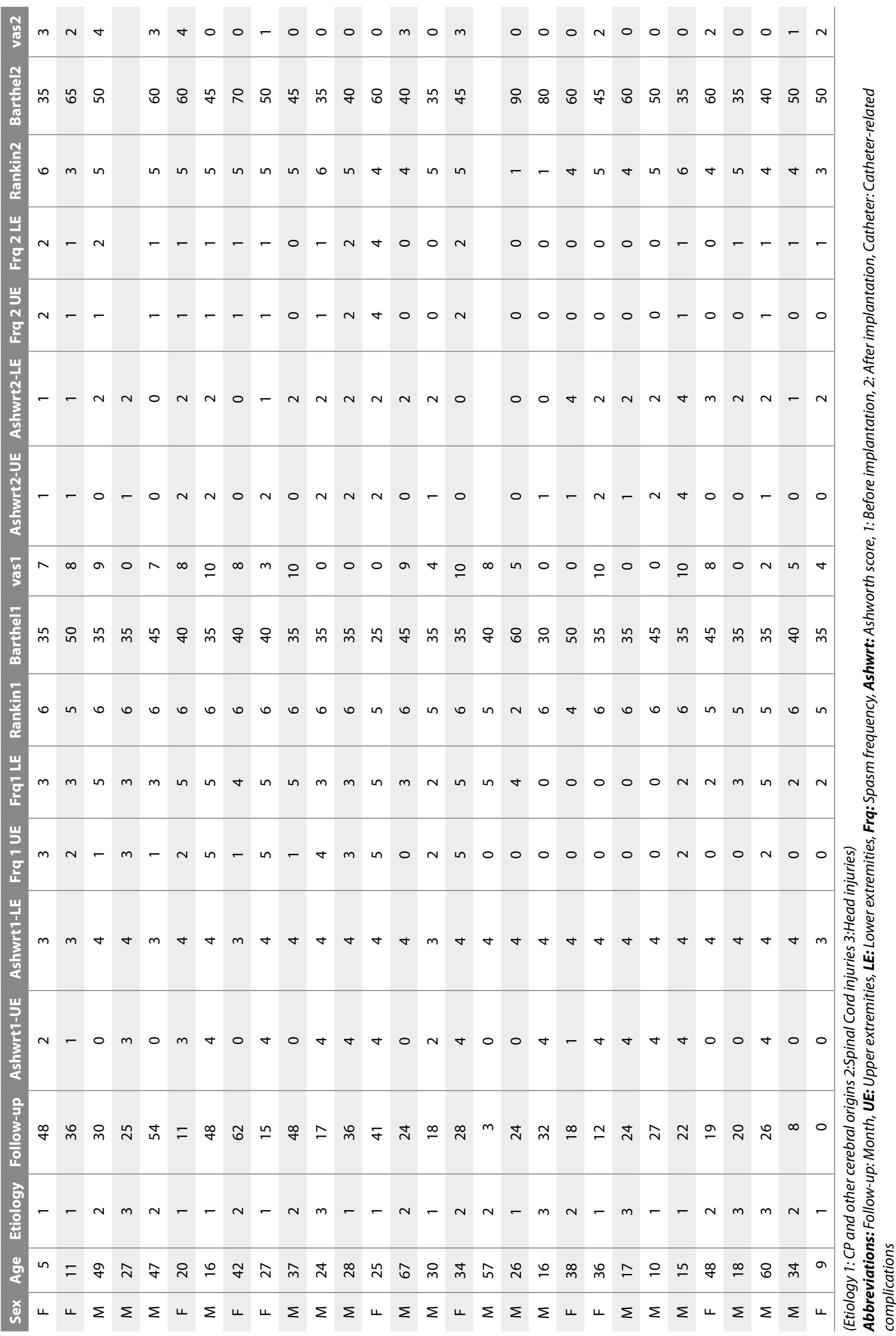




\section{RESULTS}

The mean age of the 30 patients presented was $30.10 \pm 16.09$ years. The mean follow-up period of our series was $27.60 \pm 14.66$ months (range 1 to 62 months). 5 patients were treated for more than 48 months, 8 more than 36 months.

Spasticity and spasm frequency were clinically and statistically decreased in all patients.

The mean Ashworth score of the upper extremity decreased from $2.22 \pm 1,82$ to $1.07 \pm 1.01$, and the lower extremity score decreased from $3.81 \pm 0.39$ to $1.69 \pm 1.08$ in 12 months. When we analyzed these results statistically, both of the decreasing values showed statistically significant differences $(p<0.005)$ The mean spasm score of the upper extremities also reduced from $1.74 \pm 1.81$ preoperatively to $0.82 \pm 090(p<0.005)$ and $2.96 \pm 1.78$ to $0.88 \pm 0.97$ for lower extremities respectively $(\mathrm{p}<0.001)$ (Table II)

Spasticity score and spasm frequency decreased within the first year, then tended to stabilize.

The mean BI score was $38.70 \pm 7.15$ before the treatment, and it increased to $51.62 \pm 14.69$ in 12 months. The improvement was statistically significant $(p<0.005)$ (Table II). The most dramatic improvements of motor function were observed with in the first year. Moreover, facilitation of transfer, active and passive physical therapy and nursing care were observed in all patients.

The self-assessed pain gradually decreased in all patients. The mean preoperative pain was (VAS) $4.81 \pm 4.17$ and was reduced to $1.00 \pm 1.44$. The differences were statistically different $(p<0.005)$

\section{Dosage}

The mean initial dose of ITB was $140 \mu \mathrm{g} /$ day (range 90 $\mu$ g.to $340 \mu \mathrm{g}$ ) (Table III). During the first year after the pump implantation, the dosage was progressively increased almost in all patients. Drug dosage remained stable after the first year, except for 4 patients. where dosage adjustment was required. The average test dose was $50 \mu \mathrm{g}$. The most common test dose complications were nausea/vomiting (1.6\%) and sedation $(2.4 \%)$

\section{Reasons for removing the pump}

Two pumps were removed during the study. One of them was removed with in the first month due to wound complication, including infection. Another was removed 3 years after the implantation due to financial problems.

\section{COMPLICATIONS}

\section{Infectious Complications}

In our series we have seen only 1 infection in a young adult. The pump was removed and a new pump was reimplanted 3 months later. Systematic infection has not been identified in any cases.

The most common surgical complication in our series was cerebrospinal fluid collection This was mostly seen in pediatric patient groups and was treated in a short time with an elastic bandage rather than any extra processes.

Technical Complications and Problems: The most common identified technical complication was a broken or retracted catheter, (Figure 1) (16.6\%). Catheter retraction occurred during the removal of stylet after the puncture. For this reason this procedure must be done under the continuous visualization of X Ray.

\section{DISCUSSION}

Chronic spasticity that does not respond to treatment with medication and painful spasms cause independent work and daily lives of the patients with upper motor lesion impossible by negatively affecting their mobilization, sitting, hygiene, sleeping patterns and other activities. With this study of ours, we tried not only to evaluate the neurological improvement of the ITB therapy but also to find out how much it contributes to functional recovery and painful spasms.

While the preoperative score of muscle spasms was 3.1, it postoperatively decreased to score 1 in the controlled double blind study of Coffey and his friends done with 75 patients

Table II: Comparison of Patient Responses to the Treatment and Statistical Analysis

\begin{tabular}{|c|c|c|c|}
\hline & Before Treatment (mean $\pm S D$ ). & First Year Follow-up & $\mathbf{p}$ \\
\hline $\begin{array}{l}\text { Spasticity (Ashworth) } \\
\text { Upper extremities } \\
\text { Lower extremities }\end{array}$ & $\begin{array}{l}2.22 \pm 1,82 \\
3.81 \pm 0.39\end{array}$ & $\begin{array}{l}1.07 \pm 1.01 \\
1.69 \pm 1.08\end{array}$ & $\begin{array}{l}p<0.005 \\
p<0.005\end{array}$ \\
\hline $\begin{array}{l}\text { Spasm Frequency } \\
\text { Upper extremities } \\
\text { Lower extremities }\end{array}$ & $\begin{array}{l}1,74 \pm 1.81 \\
2,96 \pm 1.78\end{array}$ & $\begin{array}{l}0.82 \pm 090 \\
0.88 \pm 0.97\end{array}$ & $\begin{array}{l}p<0.005 \\
p<0.001\end{array}$ \\
\hline Barthel Index & $38.70 \pm 7.15$ & $51.62 \pm 14.69$ & $P<0.005$ \\
\hline Pain (VAS) & $4.81 \pm 4.17$ & $1.00 \pm 1.44$ & $\mathrm{p}<0.005$ \\
\hline Rankin scale & $5.91 \pm 0.30$ & $5.10 \pm 0.56$ & $\mathrm{p}<0.005$ \\
\hline
\end{tabular}


Table III: Average Continuous Intrathecal Baclofen Infusion Daily Dose 12 Months after the Implantation

\begin{tabular}{l|c}
\hline Daily dose ( $\mu \mathrm{gr} / \mathrm{day})$ & Number of patients \\
\hline $90-120 \mu \mathrm{gr} /$ day & 9 \\
$120-170 \mu \mathrm{gr} /$ day & 14 \\
$170-240 \mu \mathrm{gr} /$ day & 3 \\
$240-270 \mu \mathrm{gr} /$ day & 3 \\
$340 \mu \mathrm{gr} /$ day & 1 \\
\hline
\end{tabular}

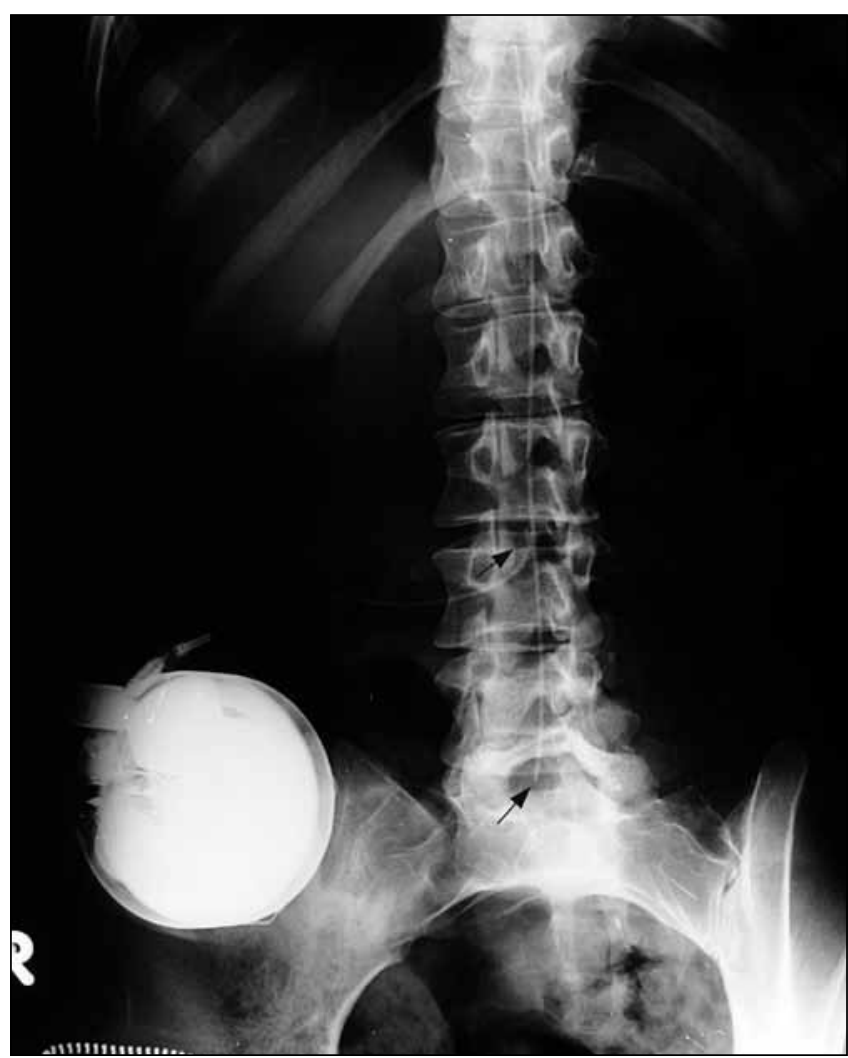

Figure 1: Arrow head showing proximal and distal tips of broken catheter.

with $\mathrm{SCl}$.(8) Similar results have been obtained from the treatment of ITB given to the 17 patients with head injury, 23 patients with CP and 7 patients with SH (Spactic Hemiplegia). In the series of Boviatsis and friends done with the patients with multiple sclerosis and $\mathrm{SCl}$, they identified a decline by 2 units each in the score of spasticity and pain in both of the groups, and they also observed that there was no difference in the level of improvement between these two groups(5)

Decreasing values of spasticity in upper and lower extremities from 1.91-3.64 to 1-1.36 and the score of the spasm frequency from 2.55-4.0 to 1.1-1.2 in our study are similar to the results above. Spasticity does not affect the clinic adversely in all patients. In some cases we may even benefit from spasticity such as the contribution of the extensor spasticity to the verticalization. (12) In this situation how much the treatment, given to the patient, changed daily activities should be taken into consideration and as in our study, the results of functional improvement should be observed with parameters such as the pain score. In this way, we can evaluate both how well the patients were selected for the treatment and the efficacy of the study more objectively. We achieved significant results, at the Barthel index and Rankin scale, indicators of functional improvement, regarding recovery of the patients at the end of this study. Pain is the main symptom and a good sign of recovery of the patients having disorders of the muscleskeleton system. At the end of the study, significant changes in the VAS values clearly show that ITB therapy contributes to not only functional improvement of the patient but also regression of the pain.

Grading of spasticity is frequently performed with the modified Ashworth scale as delineated by Bohannon and Smith (3). This test has received some criticism, specifically in its reliance on human rating and grading of tone and resistance to motion. Some authors describe augmenting the rating scale with a more inter-rater reliable technique such as using a dynamometer to quantify resistance torque during passive joint motion (1). Actually Ashworth scale received some criticism (10) and clinicians use both of them. We have used classical Ashworth to evaluate the patients.

In electrophysiologic studies done previously, the positive effects of ITB therapy were observed objectively by reflex and motor evaluations. (9) The missing part of our study is not to have a control group as in most of the series done before. However, in such an invasive study, it should not be ethical to find but deprive the control group of the treatment giving them an ineffective therapy. Instead, it is more probable to compare these therapies to those with oral medication or surgical treatment.

When the complications and our revision reasons are examined, it is observed that the most frequent problems were complications of the catheter. In a total of 5 cases (16.6\%), and one patient twice, the patients were reoperated because of the disconnection and migration of the catheter. We think that the origin of the complications related to the catheter is the very thin and vulnerable structure of the intradural catheter. It seems that because of this thin structure, the sharp edge of the puncture needle weakens the catheter in every insertion by causing microtrauma to the wall of it and within the following period causes breaks. A series of 102 patients at Rush University Medical Center in Chicago demonstrated a $40 \%$ catheter complication rate. (20) Catheter kinks and holes were responsible for $50 \%$ of the failures. Other failure modes include disconnection of the catheter from the pump, dislodgement from the intrathecal space, and rarely, fibrosis at the catheter tip blocking flow. In our series we have never seen any of them so far.

Infection of the implanted baclofen pump or catheter occurs at a steady rate, 4/100 in a recent series of children with spasticity. (11) Surgical removal is almost always necessary 
with subsequent reimplantation in an alternative surgical site after the infection is treated. We have seen only 1 infection in our cases.

As we stressed earlier our patients needed larger dosage especially the following year of the procedure. In this situation, the system must be checked before the dose modification. Analysis of the pump and catheter system is required in patients already implanted with a baclofen pump who develop acute alterations in their drug requirement or spasticity level. It is important to exclude any new medical problems during the initial evaluation. The pump's battery life, mechanical function must be evaluated. If the pump telemetry suggests that all mechanical functions are sound and that the pump has adequate battery function, an analysis of the system can be undertaken. X-rays of the pump and catheter system should be obtained and analyzed for migrations of the catheter tip, disconnections of the hub-catheter interface, or kinking or curling of the catheter system (14)

Another important point is the patient selection criteria. In the classical literature, it has been suggested that the patient must be treated with conservative ways/methods for at least 6 months. However, according to our clinical observations waiting causes formation of contracture which cannot be relaxed later on. We hypothesized that the early administration of intrathecal baclofen may help in preventing such osteotendinous complications. Therefore, we have recently started using ITB treatment in a short time, before a contracture forms, in the cases which we used to wait for at least 6 months previously, and we have got positive results from that

The financial side of ITB therapies is another important problem. Thus, prevention of the spasticity must always be the first plan. If the spasticity has already occurred, a cost study on the selected surgical method must be done as ITB therapies are really expensive treatment alternatives. Since it is not our priority to compare and contrast the costeffect, it is not possible for us to conclude the advantages and disadvantages of ITB therapy when compared to all other treatments. However, from now on, we need to have studies to be able to evaluate it from this point of view. In one of the comparative studies done on this issue, Postma et al. concluded that the costs of the therapy (continuous intrathecal infusion of baclofen) can be attributed mostly to the implantation of the pump and related to hospitalisation days. Savings originated from withdrawal of oral medication, job preservation and avoidance or delay of admission to a nursing home (22). We need to have much more comparative studies for a precise opinion on this issue.

\section{CONCLUSION}

ITB therapy increases the quality of lifestyle and functional independence by reducing not only cerebral but also spinal related spasticity in appropriately selected cases. It is necessary to have much more controlled studies to achieve more accurate and precise outcomes of ITB therapy.

\section{REFERENCES}

1. Anderson WS, Jallo GI: Intrathecal Baclofen Therapy and the Treatment of spasticity. Neurosurgery Quarterly 17(3):185-192, 2007

2. Ashworth B: Preliminary trial of carisoprodol in multiple sclerosis. Practitioner 192:540-542,1964

3. Bohannon RW, Smith MB: Inter-rater reliability of a modified Ashworth scale of muscle spasticity. Phys Ther 67:206-207, 1987

4. Borowski A, Aaron G, Littleton, BS, Battugs B, Ana P, Suken S, Kirk W D, Sharon L, Maura McMannus, Freeman M: Complications of intrathecal Baclofen Pump Therapy in pediatric patients J Pediatr Orthop 30(1):76-81, 2010

5. Boviatsis J, Stefanos K, Damianos E: Functional outcome of intrathecal baclofen adminastration for severe spastisity. Clinical Neurology and Neurosurgery 2004

6. Brian HK, Debra S, Werner KD, David SF, Jeffrey HW, Howard LW: Subfascial implantation of intrathecal Baclofen Pumps in Children: Neurosurgery 49(3):753-757, 2001

7. Bruno F, Vacher P, Jerome R, Salle JY, Vidal J, Moreau JJ, Vignon P: Intrathecal Baclofen after traumatic brain injury: Early treatment using a new technique to prevent spasticity. Journal of TraumaInjury Infection \& Critical Care 50(1):158-161, 2001

8. Coffe Y JR, Cahil D, Steers W: Intratechal baclofen for intractable spasticity of spinal origin: Results of along term multicenter study. J Neurosurg 78:226-232,1993

9. Dachy B, Dan B: Electrophysiological assesment of the effect of intrathecal baclofen in spastic childeren. Clinical Neurophysiology 113:336-340, 2002

10. Damiano DL, Quinlivan JM, Owen BF, et al: What does the Ashworth scale really measure and are instrumented measures morevalid and precise? Devel Med Child Neurol 44:112-118, 2002

11. 60. Gooch JL, Oberg WA, Grams B, et al: Complications of intrathecal baclofen pumps in children. Pediatr Neurosurg 39: $1-6,2003$

12. Grabb P, Pittman A: Subfascial placement of baclofen pumps. Presented at the 27th Annual Meeting of the Section on Pediatric Neurological Surgery, Indianapolis, Indiana, December 1-4, 1998

13. James D W L, Teresa LM: Spastisity and associated Abnormalities of muscle tone. Rehabilitation Medicine. Principles and practice. 3th ed. DeLisa 2:997-1009,1998

14. Lousber PG, Narayan RK, Sandin KJ, et al: Continuous infusion of intratechal baclofen:Long -term effects on spasticity in spinal cord injury. Paraplegia 29:40-64, 1991

15. Mahoney Fl, Barthel DW: Functional evaluation: The Barthel index. Maryland State Medical Journal 14:61-65, 1965

16. McCall TD, MacDonald JD: Cervical catheter tip placement for intrathecal Baclofen administration. Neurosurgery 59(3):634-640, 2006

17. Meythaler JM, Devivo MJ,Hadley M: Prospective study on the use of bolus intrathecal Baclofen for spastic hypertonia due to acquired brain injury. Arch Phys Med Rehabil 77: 461- 466,1996

18. Meythaler JM, Guin-Renfroe S, Grabb P, Hadley MN: Long-term continuosly infused intratechal Baclofen for spastic- Distonic Hypertonia in traumatic brain injury: 1 year experince. Arch Phys Med Rehabil 80(1):13-19, 1999 
19. Stempien L, Tsai T: Intrathecal Baclofen Pump use for spasticity. A clinical survey intrathecal Baclofen pump use for spasticity: A clinical survey. Am J Phys Med Rehabil 79:536-541, 2000

20. Penn RD, York MM, Paice JA: Catheter systems for intrathecal drug delivery. J Neurosurg 83:215-217,1995

21. Penn RD, Kroin JS: Continuous intrathecal baclofen for severe spasticity. Lancet 20:125-127,1985
22. Postma M, Oenema D, Kuipersupmeijer J. Staal MJ, Middel BJ: Cost analysis of the treatment of severe spinal spasticity with a continuous intrathecal Baclofen infusion system. Pharmaco Economics 15(4): 395-404,1999

23. Rankin L: Cerebral vascular accidents in patients over the age of 60. II. Prognosis. Scott Med J 2:200 -215, 1957

24. Vender JR, Hester S, Rekito AL, Mark R: Baclofen Intrathecal Pump Delivery Systems: Avoidance and management of complications in adult and pediatric patients: Part II. Contemporary Neurosurgery $27(2): 1-5,2005$ 